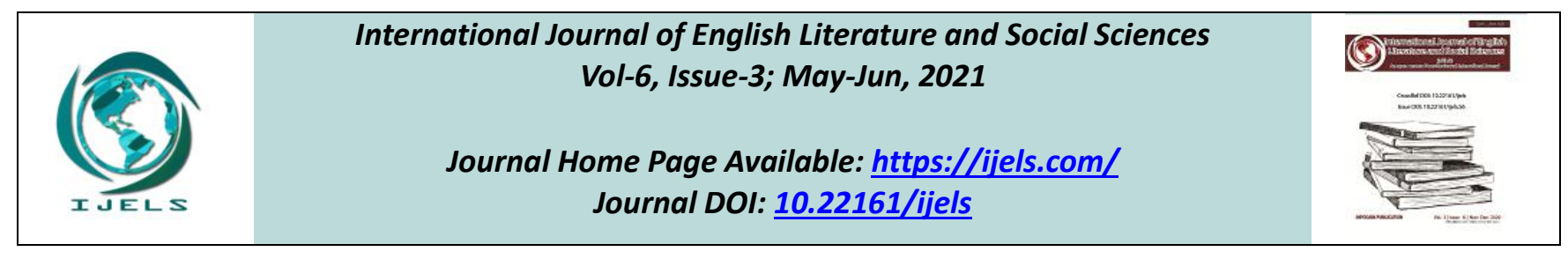

\title{
The Outsider in Wuthering Heights
}

\author{
Ayman Khaled Hussein*, Prof. Madya Mohd Nazri bin Latiff Azmi
}

Faculty of Languages and Communication, Universiti Sultan Zainal Abidin, Gong Badak Campus, 21300 Kuala Nerus,

Terengganu, Malaysia

*Correspondence author

Received: 21 Mar 2021; Received in revised form: 28 Apr 2021; Accepted: 14 May 2021; Available online: 07 Jun 2021

C2021 The Author(s). Published by Infogain Publication. This is an open access article under the CC BY license

(https://creativecommons.org/licenses/by/4.0/).

\begin{abstract}
This study focuses on the racial and postcolonial methods as ways of reading and understanding literary texts. By applying them to literary works, one can study characters and verify their issues and suffering at some point in the course of their life within the top-quality novel. Critical and analytical, these two approaches expose the suffering of characters who try to fit in society due to racial discrimination, so the human principles are not valued or considered, leaving the characters to fight and struggle severely. This study displays how the biased society treats the character in the given work as an outsider. Thus, this study investigates one outsider, Heathcliff, by realizing the negative impacts of the racial and postcolonial approach to his life. Heathcliff is the protagonist in Wuthering Heights that Emily Bronte (1818-1848) wrote in 1847. This paper looks into the reasons for Heathcliff's alienation and suffering in society due to his race, origin, and color. One can noticeably grasp his severe suffering, difficulties, and alienation in this work.
\end{abstract}

Keywords—Heathcliff, Wuthering Heights, Outsider, Racism, Postcolonialism.

\section{INTRODUCTION: RACISM AND POSTCOLONIALISM}

According to what is stated by UNESCO in the Declaration on Race and Racial Prejudice: "Racial prejudice, historically linked with inequalities in power, reinforced by economic and social differences between individuals and groups, and still seeking today to justify such inequalities, is total without justification." (1978, article 2, p.2)

The topics of inequality and racial discrimination and their negative effects on people in society have been elaborately discussed in many literary works. Race, color, origin, national or ethnic origin are considered the criteria for any distinction, exclusion, or preference. Consequently, society views these people as outsiders who are ill-treated and dehumanized unwillingly. Then, these outsiders quest for their identities with lots of dangers, suffering, and oppression. In fact, racism acts as an undesirable factor that promotes inequality, hatred, and revenge. This merciless factor springs from prejudicial principles that have been used to treat others unfairly. Unfortunately, the result of the atmosphere where racism works and affects others is a core of classification between whites and blacks and masters and slaves.

Racial discrimination between classes in society causes conflicts. Thus, nobles fight against the lower classes, and they become proud of their wealth, nobility, intelligence, and origin. They believe their superiority enables them to dominate the poor and treat them as their slaves.

This paper highlights the influence of racism that is a prominent social problem that many critics have dealt with. Therefore, this study deals with the theme of "the outsider" in Wuthering Heights in the context of racial and postcolonial discrimination and describes the anguish of the alienated characters - the outsiders. Racism leads the outsiders to the state of marginalization and traps them in accordance with the social restrictions. The alienated characters are disdained since the superior group in society considers their races inferior. As a result, these outsiders 
are dehumanized and detached from normal life in society. Moreover, society rejects them due to their race and color and gives no respect to their human nature. These outsiders are oppressed and prevented from becoming popular insiders in society. The outsiders lack normal relationships with people whose races and origins are considered inferior by the superior and arrogant characters. Clearly, there is a fight to force some races aside while others rule and dominate, giving the inferior the worst chances to live normally in society. The prejudiced groups get no good chance to prove themselves or fit normally in society.

Arrow (1998) says: "Racial discrimination pervades every aspect of a society in which it is found. It is found above all in attitudes of both races, but also in social relations, in intermarriage, in a residential location, and, frequently, in legal barriers." (p.1)

Obviously, racial discrimination is a barrier that stands against certain individuals who have their own and normal roles to play in society. However, they can't do that because they are belittled and helpless in society. Michael Banton (1979) presents the words of Abraham Lincoln in 1862. Lincoln depicts the core of racial discrimination that differentiates between groups in society; he is addressing some people who are black American:

\begin{abstract}
'You and we are different races. We have between us a broader difference than exists between any other two races. Whether it is right or wrong I need not discuss, but this physical difference is a great disadvantage to us both; as I think your race suffers very greatly, many of them by living among us, while ours suffer from your presence'. (p. 1)
\end{abstract}

Racism is the basis of the mysterious events and miserable conditions that lead to isolation, agony, destruction, and killing love. The alienated is the stranger who is struggling to live normally and peacefully, but he is not given this chance. In Bronte's Wuthering Heights, a clear example is the case of Heathcliff who is alienated and humiliated, paying no attention to his humanity. $\mathrm{He}$ cannot choose to love or reveal his love to Catherine in a society that despises his race, ignoring his right as a human being to love and express his emotions.

Racial prejudice causes the outsider to lose his identity, so he lives with no regard for his humanity or human feelings. Since the despairing person is depressed and angry, his or her acts become negative and harmful, and eventually useless. Furthermore, these acts would undoubtedly kill people and create an unstable environment for social tensions despite the individual's best efforts to fit into society.

The essence of political and economic circumstances limits and affects individuals' freedom due to the impact of racial discrimination. The individuals who are oppressed have no position in the world of liberty; they will face inequity, injustice, and alienation. They become mere weak victims to the spirit of colonialism and racial discrimination. In the world of postcolonialism, there isn't equality. Young (2003) says that all people have the right to the same material and cultural well-being in postcolonialism; however, the irony is that the world today suffers from inequalities and a wide division between Westerners and non-Westerners.

The colonial conditions result from the postcolonial factors that many nations have been fighting since they are against humanity and fair treatment. The European conquests, several organizations of colonialism, and the broad actions of an empire have been analyzed to see their impacts in the fields of history, politics, sociology, and economy (Ashcroft et al. 2007, p.169).

Accordingly, all people should respect the humanity of all groups in society without any preferential treatment to specific races. The origin, color, or race can't be the criteria to respect or humiliate others. All are equal, so no one will be deprived of freedom. All races should be free and well-treated. Besides, the relations between the superior and the inferior have to be built based on reason and humanity, away from postcolonial racism and impacts.

\section{HEATHCLIFF THE OUTSIDER}

This research investigates the impact of racism on societal division and alienation. Being a biased assumption, the theme of the stranger has been the subject of numerous studies. Thus, as this study is critical and analytical, it deals with the theme of the stranger in Wuthering Heights in the light of racial and postcolonial aspects. Furthermore, this paper examines this novel in order to discuss the protagonist's suffering and the loneliness that torments him. Heathcliff's life and interactions with the characters are the subjects of this research. His life is examined in Wuthering Heights and the Thrushcross Grange, the two main sites in Wuthering Heights that Emily Bronte (1818-1848) wrote in 1847.

Wuthering Heights is a novel written in 1847 that presents a strong analysis of social norms. Heathcliff, an orphan from Liverpool's marginalized neighborhoods, is adopted by the Earnshaw landlord. Mr. Earnshaw's life has been drastically disturbed as a result of Heathcliff's intrusion into this family. Earnshaw's family regards him 
as a stranger, pushing him away from being one of them. $\mathrm{He}$ is not given the chance to be an insider; he is labeled an outsider. Heathcliff's appearance is not accepted and contributes to his alienation. It is the cause of his inferior status in the family. In other words, Heathcliff's true identity is unknown to anyone. A lot of attention has been given to Heatchliff's appearance that makes him live as a strange and different outsider. Heathcliff is trapped in a state of isolation due to cruelty, dehumanization, and injustice even when he is too young. Heathcliff's life has become pointless and torturing. Not only society considers his race as the basis of rejecting him as an insider, but it also pays no consideration to the fact that he is a human being. Sadly, he is suppressed, expelled, and prevented from becoming an insider by society. His relations to mix with other people are doomed unsuccessful.

From the moment he arrives at Wuthering Heights until his lonely death, Heathcliff will struggle with fear and loneliness. His life conditions demonstrate that he is an outsider who is despised, alienated, and mercilessly destroyed by society. Thus, Heathcliff's miserable upbringing, his love for Catherine, his vengeance, and his last days of loneliness will all be investigated to show his state of alienation.

With exception of Catherine, no one understands Heathcliff's feelings. Their love has a special pure quality to it that makes it romantic. Heathcliff demonstrates an honest affection for Catherine, and the tale of love remains to be extraordinarily appealing in Heathcliff's tragic life. The touching framework of feeling loved in his life is his divine commitment to Catherine.

\section{HEATHCLIFF THE GYPSY}

Heathcliff is thought to be Mr. Earnshaw's illegitimate child whom he brought from a poor district in Liverpool. Nothing is known about his true origins because his birth is unknown. The members of Mr. Earnshaw's family have been shocked as a result of his unexpected arrival and existence among them.

Terry Eagleton (2005) comments on Heathcliff's troubling arrival at Mr. Earnshaw's house in his article on Wuthering Heights and says that Heathcliff comes in as an outsider from the ambiguous realm of darkness. That darkness is ambiguous as it seems that he will be both a blessing and a challenge in the novel. He is an outsider to the family's domestic environment.

Heathcliff settles in Wuthering Heights, so he is now close to the barren and harsh wildlife of the moors. With the exception of Catherine, who is a little younger than him and becomes a childhood friend of Heathcliff's, the members of Mr. Earnshaw's family classify Heathcliff as a gypsy who is unequal to them. Heathcliff's presence is defined in the story as that of an outsider or a gypsy from Europe's lowest social class. Heathcliff is treated harshly from the moment he arrives at Mr. Earnshaw's home, with little regard for his identity as a human being with the right to play, love, and receive respect. The family recognizes Heathcliff as a black and dirty boy; this is enough to belittle and despise him from the very beginning. Mr. Earnshaw's family's reactions to Heathcliff's arrival are narrated by Nelly as follows:

We crowded round, and, over Miss Cathy's head, I had a peep at a dirty, ragged, black-haired child; big enough both to walk and talk; indeed, its face looked older than Catherine's, yet, when it was set on its feet, it only stared round and repeated over and over again some gibberish that nobody could understand...asking how he could fashion to bring that gypsy brat into the house. (Wuthering Heights, p.39)

As mentioned in the introduction, the boy has a difficult time getting along with the white and wealthy family. As an example, the family would not allow this gypsy, who is an outsider, to stay with them. These prejudiced members of society regard Heathcliff as an animal, ignoring his humanity. The family refers to Heathcliff as " $i t$ " and depicts his position while sitting on his feet, being symbolic as that of an animal. Moreover, using the pronoun "it" to refer to Heathcliff can be minimizing his role to be a normal member of society.

That kind of thinking is abhorrent to human dimensions when directed at someone who is still a vulnerable child. As a helpless infant, Heathcliff has no ability to defend himself; he is unable to shield himself from social humiliation and torture. Especially that no one can protect Heathcliff after the death of $\mathrm{Mr}$. Earnshaw. What is worse is that Catherine is also unable to oppose her society's racial practices. Almaraee and Heidarzadegan say:

Due to the calamities, psychological pressures, and anxiety, and instability they experienced. Previous works are limited to discussing the issue of alienation in the novel in general so, in this part, the researcher takes a new look at the issue of alienation in the novel and what are the reasons that led to it and its impact on Heathcliff in a special way 
and the rest of the characters in general. (2021, p.46)

Since Mr. Earnshaw favors Heathcliff rather than Hindley, Hindley has become envious of Heathcliff and has begun to attack him. Even after his father's death, Hindley is the new lord of the Heights, and he has been humiliating Heathcliff more cruelly than before. The treatment that Heathcliff receives as a stranger reflects his marginalization and the prejudice in Hindley's society. That kind of unjust treatment is very humiliating to Heathcliff's human status. The way Hindley treats Heathcliff demonstrates society's denial to consider Heathcliff as an insider. The tyranny of Hindley becomes severe as he forces Heathcliff to have no company to the servants, labor out of doors, and work harder than any other lad on the farm.

Heathcliff, on the other hand, demonstrates a high level of resilience in his passive reactions to Hindley's vindictive mistreatment of him. Heathcliff is unusually quiet and tolerant; Nelly remarks on Heathcliff's calm manner, saying:

He seemed a sullen, patient child; hardened, perhaps, to ill-treatment: he would stand Hindley's blows without winking or shedding a tear, and my pinches moved him only to draw in a breath and open his eyes as if he had hurt himself by accident, and nobody was to blame. This endurance made old Earnshaw furious... (Wuthering Heights, p.40)

Heathcliff's feelings are actually passive at this point because he is frail, powerless, and unable to stand up to Hindley, his master. Heathcliff's loneliness is unbearable, and no one can save him. Only Catherine and Nelly can sympathize with him; however, they can do nothing now to help him or stop him from being alienated. When Catherine is injured, the Lintons refuse to accept Heathcliff; they are rich who refuse the gypsy. Although the Lintons welcome Catherine and look after her, they shockingly attack Heathcliff as a stranger.

Heathcliff enjoys and feels close to nature where there are no restrictions. He is not subjected to many societal stresses. Heathcliff seeks to avoid society because he lacks the opportunity to learn o to be educated and civilized. As a result of society's removal of him from elements of humanity, he remains a victim of a society that deprives him of even being civilized. Being close to nature, Heathcliff feels safe and satisfied. He is not a member of society, nor he plays any social role. Catherine shares his desire to be away from the sick environment that resents him and rejects their unity. It is his pleasure to take her into the wild areas away from the Heights.

\section{HEATHCLIFF AND CATHERINE}

The key theme of Wuthering Heights is Catherine and Heathcliff's grand friendship. Catherine's sympathy for Heathcliff runs parallel to the overarching theme of innocent and pure love. A close and genuine attraction between two kids is an important part of their love that is not ordinary; it's transcendental, bringing two souls together. One can recognize that their love is an alternative to the injustice that society has placed on them. Later, as society tries to destroy Heathcliff's love for Catherine, Heathcliff develops a desire for vengeance, which he nurtures for years. Nelly talks about the pure bond of love between Heathcliff and Catherine. She says that Heathcliff and Catherine love each other strongly. And the worst punishment for Catherine is to force her away from him.

However, society interferes rudely and limits their natural love by imposing the social forces of alienation, social hierarchy, and racism, so they are disappointed by the society as they grow up in it. They run to nature where their love is valid. Their union is only possible with no restrictions only when they abandon the real world and social racial codes. When they are together, they are in an attractive, complete, and satisfying union, but this union is not allowed in society.

The little souls were comforting each other with better thoughts than I could have hit on; no person in the world ever pictured heaven so beautifully as they did, in their innocent talk; and, while I sobbed, and listened I could not help wishing we were all there safe together. (Wuthering Heights, p.46)

The founders of Wuthering Heights and the Thrushcross Grange are enraged by Heathcliff's affection for Catherine. As a result, Catherine and Heathcliff are unable to marry. Cathy becomes staunch of Heathcliff. Her relationship with Edgar is a social approach to helping Heathcliff. Readers recognize that their love is the catalyst for the story's tragic conclusion, creating an environment of hate, vengeance, and tragedy among the other characters Heathcliff encounters. As Catherine tells Nelly about her deep love for Heathcliff, she emphasizes the truth that her love for Heathcliff is deep and everlasting. Her words show how wondrous their love is Catherine says:

He will, when he learns my true feelings towards him. Nelly, I see now you think me a selfish wretch; but did it never strike you that if Heathcliff and I 
married, we should be beggars? whereas, if I marry Linton, I can aid Heathcliff to rise, and place him out of my brother's power.' (Wuthering Heights, p.87)

\section{HEATHCLIFF'S RETURN}

Heathcliff is unable to have normal relationships with others in society because of his vague and unaccepted origin. He struggles in a society in which he is obliged to live, so he is entrapped and labeled "the stranger". In fact, since Heathcliff is a gypsy, society hates him. With his present reality, he is unable to battle and face society. Living with his dehumanized personality, money and gentleness are far away from him. As a result, he makes the decision to leave his life of dehumanization and humiliation, but only for a short time. Heathcliff has gone to an unknown destination that will remain a mystery. For a while, he reappears, armed with the same powers that society used to battle and hate him: he is now a wealthy gentleman. Society, surprisingly, pretends to tolerate him and briefly forgets about his origins. While Heathcliff is now a wealthy gentleman, he has become a brutal "monster" against the Lintons and Earnshaws. The hostility that society has developed instills in him a similar level of hatred towards others. Furthermore, his responses are emotionally the product of his heart being torn and leaving him in suffering and alienation. Heathcliff emphasizes the belief that humans teach and move him cruelty because no one has ever respected his emotions.

You teach me now how cruel you've been-cruel and false. Why did you despise me? Why did you betray your own heart, Cathy? I have not one word of comfort. You deserve this. You have killed yourself. Yes, you may kiss me, and cry; and wring out my kisses and tears: they'll blight you-they'll damn you. You loved me - then what right had you to leave me? What right-answer me-for the poor fancy you felt for Linton? (Wuthering Heights, p.173)

Heathcliff reappears after a long absence, transformed from a bad creature by birth to a wicked and pitiful man defaced in society. Heathcliff's and everyone else's lives are worsening as a result of this inequality, which is ultimately insulting and inhuman. This time of transition represents the opposition of the oppressed to society's rules and regulations. There is clearly a contrast between Heathcliff's personality before and after his disappearance. He used to be weak, modest, powerless, and patient, but now he has a new identity: he is evil, cruel, vindictive, and authoritarian. Despite the fact that readers are aware of Heathcliff's new persona, they are aware of his state of isolation, i.e., while he is helpless, society rejects him, and when he is wealthy and a tyrant, society is still the enemy.

\section{HEATHCLIFF'S SEVERE REVENGE}

Wuthering Heights focuses on the class struggle and ethnic conflict that exists between members of society from various social groups. Racism is a major aspect of the tumultuous struggle between members of various social groups. Because of the competitors' position in this battle, there will undoubtedly be losers. Racism is a sign of devastation because of its cruelty and inequality, and it traps individuals in a state of "outsideness" and renders them incapable of enduring degrading and dehumanizing misery. Heathcliff is socially labeled "the stranger". As a result, his life becomes dehumanizing. Eventually, society rejects him, ignoring the human aspect of this intruder. Since society, bizarrely, defeats, expels, and prevents him from adapting, Heathcliff has no positive interactions with people in society. As a result, this novel delves into a psychological examination of Heathcliff, who is torn between love and hate, and portrays the pain of all members of the family who participate in prejudice towards the dignity of the oppressed characters. Heathcliff's hate is directed mostly at everyone but Catherine, whom he loves profoundly and passionately. Althubaiti (2015) highlights the concept of racial discrimination in Wuthering Heights and says that it is clear how Heathcliff is produced as a man with petty black eyes in a prejudiced society; Heathcliff is constantly degraded and isolated. Althubaiti also believes that Heathcliff has never been considered truly human, and his human rights have always been deprived.

Since Heathcliff, the outsider, is unable to embrace society's unjust rules, racism creates a mysterious and ominous environment, forcing him to live in a state of loneliness and isolation. What is clear is the idea that since the class struggle has unfairly put Heathcliff at the bottom of society and Linton at the top, hatred has succeeded in replacing love and affection among the characters in this society. The capitalistic society fights Heathcliff who wants to fit in, so he starts fighting it using the same method. As a result, he continues to participate in society as a vengeful gentleman. Heathcliff decides to retaliate ruthlessly and harshly. His societal attitudes and viewpoints are negative and unwelcome. Heathcliff, in other words, now resides in a world of wickedness, hate, and evil force. His heinous actions are a result of society's mistreatment of him. Now, Heathcliff is wearing the mask 
of revenge in order to question his state of alienation and take strong action against the culture that has enslaved him because of his race. In retaliation for Isabella's brother Edgar's marriage to Catherine, Heathcliff treats her brutally. Isabella says that Heathcliff is not a human being and she hates him. He has destroyed her heart with his cruelty.

As an outsider, Heathcliff descends into a state of devastation that extinguishes the passion and love that the stranger has had the right to have. Heathcliff's pain causes him to leave for a time in order to stand and struggle against the high and bourgeois aspects. Heathcliff transforms into a ruthless capitalist landowner intent on exacting vengeance on both the Earnshaws and the Lintons. Heathcliff is believed to be a person who tortures himself since he struggles with the racist and imperialist codes in that society.

All those who have fought and stood against Heathcliff's love in the name of discrimination and inequality are treated with cruel detestation by Heathcliff. Heathcliff is now the character who is the maddest, blaming Edgar and Linton for denying him Catherine and punishing Hindley for preventing him from marrying or being with her in society. His agony propels him from the state of being tortured to the role of being the torture weapon. Being a gentleman now with money and lands, Heathcliff returns to the capitalist system for revenge, and he would react unreasonably.

Catherine thinks her marriage to Edgar will protect Heathcliff; however, that changes the course of the events in the story and makes Heathcliff take revenge on all. Heathcliff thinks it is the Selfishness of Catherine that destroys him and can be understood from the deeds of Catherine. Heathcliff becomes sadder and frustrated as he is informed about Catherine's illness. Following Catherine's death, he becomes brutal in his pursuit of vengeance against Edgar and Hindley. Heathcliff wants to live for vengeance, so he seeks to do it in the coming days. He also wants to be in charge of all of the land. As a result, as a cruel and evil person, he decides to gain all of the property of the two families. There is no love in his heart. Since his beloved isn't around to lessen his revenge or soothe his rage, love has deserted his spirit.

Heathcliff intends to use his son as a means of vengeance in order to inherit Linton's lands. Heathcliff believes that a union between Linton and Cathy would allow him to become the owner of Linton lands and then he officially inherits his uncle's lands. Linton's land will be Heathcliff's. Although Heathcliff's son becomes gravely ill, Cathy is forced to marry Linton. Readers will understand Heathcliff's spirit of vengeance in these incidents, ignoring the feelings of the other characters. He is guided by a spirit of vengeance, so he is using his son to achieve his objectives and to battle society. Heathcliff's stance is so shocking that readers are taken aback as they see his retaliation progressing to damage the vulnerable and innocent. Heathcliff turns into an emotionless beast, and his need for vengeance far outweighs the marks. Heathcliff turns into an emotionless beast, and his need for vengeance exceeds the marks.

Even though young Linton dies, young Cathy is forced to stay at Wuthering Heights. Young Linton is a disappointment and the result of hate, and he shares his parents' negative characteristics: a poor mother and a cruel father. Heathcliff now owns all of Earnshaw's and Linton's houses, but he still loses his son and any potential hope for his race to survive in a society in the future.

Heathcliff forces Hareton, Hindley's son, to marry the younger Catherine in order to continue the cycle of vengeance. Heathcliff forces Hareton to live a hard and uncivilized life, almost like the one he had before. Hareton's character, on the other hand, is somewhat different from Heathcliff's; he is much more forgiving and kinder.

Hareton's friendship with Cathy is identical to Heathcliff's with Catherine Earnshaw before him. The love of Cathy and Hareton is unaffected by social constraints or conflict. On the other hand, they become fast friends and continue to live together. True love's descendants are born from their union. Young Catherine and Hareton are heading to the Grange to start a new life and form a new generation. They ignore all the suffering and social conflict, so their true love has produced a happy marriage in which Cathy will look after Hareton. Although Heathcliff has planned to make Hindley's son humiliated, uncivilized, and uneducated, Hareton is saved and becomes literate and civilized. Heathcliff and Isabella's marriage is different from the marriage of the new generation. Heathcliff's marriage produces hatred, mixed with his disgusting blood that is banned and estranged by society, so his race and linage will not live any longer.

Heathcliff succeeds in accomplishing his revenge and acquiring all the lands despite his overwhelming desire for vengeance. However, he begins to change after a while; he becomes more anxious and disturbed than before. He now accepts death and wishes to die so that he may rejoin Catherine spiritually in nature, where he feels free. He now accepts death and wishes to die so that he may rejoin Catherine in nature, where they are free. As Heathcliff has known hate, vengeance, and separation in society, he now knows love and union with Catherine in nature. Heathcliff is about to give up society and stay in nature. He starts 
losing a sense of what is going around him. Everything is strange to him. Everything is alienated for him. Heathcliff is constantly reminded of Catherine, so he wants to be in nature with her. Now, Heathcliff goes without eating or sleeping for the rest of his life, becoming increasingly alienated from his family. Life is tasteless, what is remaining in the spirit of Catherine that he is after in nature; he impatiently wanders through the countryside, imagining Catherine in the great outdoors. He can't stand what's going on in this society and dies on Catherine's bed; he is buried next to Catherine's grave, as he has wished. For him, the graveyard is more valuable than remaining in a world that opposes and alienates him. He has been with Catherine in nature as a boy, and now he is with her in nature again, but underground.

\section{CONCLUSION}

Heathcliff and Catherine's sincere relationship is wonderful because it is free of social and ethnic barriers. Without forgetting Heathcliff, Catherine makes sacrifices to protect him and help him survive peacefully in society. Heathcliff is a victim of her culture because of race. At the end of the story, Heathcliff learns that he won't be able to blend in, nor can he survive as a master in this racist and cruel society.

Tragically, Heathcliff abandons humanity to unite with Catherine's spirit in nature, which is more valuable and eternal. Outside of society, Heathcliff and Catherine share a special kind of love that is vibrant and fantastic; their love is possible and protected when they spend their childhood in nature and when their souls leave society. Nelly depicts the last scene between the two lovers as they lie together in their graves in nature where their full unity is achievable.

Edgar Linton's only harmonized by the turf and moss, creeping up its footHeathcliff's still bare. I lingered round them, under that benign sky; watched the moths fluttering among the heath and hare-bells; listened to the soft wind breathing through the grass; and wondered how anyone could ever imagine unquiet slumbers, for the sleepers in that quiet earth. (Wuthering Heights, p.369)

Heathcliff is humiliated and denied the right to be recognized as a human being who lives normally by society; he is unable to fit, mix, or love freely. Instead, his origin and race make him a stranger. He cannot choose who to love in society. No respect is given to his emotions or humanity. He suffers greatly because society does not value his humanity. Despite Heathcliff's best efforts to maintain his humanity and find a gorgeous love, society confronts him, ruins the lives of the two lovers, and calls him "the stranger".

As for the alienation faced by the rest of the characters, it is interwoven in one way or another with Heathcliff's alienation such as Catherine and Isabella. Brontë demonstrates the alienation distinctly artistic by revealing the nature of the relationship between the characters. She reveals the contradiction between the worlds of dream and reality experienced by some characters which was mostly characterized by collision and opposition, which increases alienation. (Almaraee and Heidarzadegan, 2021, p.51)

\section{REFERENCES}

[1] Althubaiti, T. S. (2015). Race Discourse in Wuthering Heights. European Scientific Journal, 11(8).

[2] Almaraee, Z. \& Heidarzadegan, A.P.N. (2021). Alienation as a traumatic result of racism in Wuthering Heights, To Kill a Mockingbird, and Beloved (Master's Thesis). Retrieved from http://acikerisim.karabuk.edu.tr:8080/xmlui/bitstream/handl e/123456789/1051/10378302.pdf?sequence=1\&isAllowed= y

[3] Ashcroft, Bill, Griffins, Gareth and Tiffin, Helen. (2007). Key Concepts in Post-Colonial Studies. London: Routledge. http://staff.uny.ac.id/sites/default/files/pendidikan/else$\underline{\text { liliani- }}$

$\underline{\text { ssmhum/postcolonialstudiesthekeyconceptsroutledgekeygui }}$ des.pdf

[4] Arrow, K. J. (1998). What has economics to say about racial discrimination? Journal of economic perspectives, 12(2), 91-100.

[5] Banton, Michael. (1979). The Idea of Race. Cambridge: Tavistock Publications Limited.

[6] Bronte, Emily. J. (2010). Wuthering Heights. YOGeBooks. Retrieved from http://www.yogebooks.com/english/bronte/1847wutheringh eights.pdf

[7] Eagleton, Terry. (2005). Myths of Power: A Marxist Study of the Brontes. New York: Palgrave Macmillan. Retrieved from

https://the-

eye.eu/public/Books/Bibliotik/2/2005\%20Terry\%20Eaglet on $\% 20-\% 20$ Myths $\% 20$ of\%20Power $\% 20$ $\% 20$ A $\% 20$ Marxist $\% 20$ Study\%20of\%20the\%20Brontes $\% 5$ BAnnEd\%5D_Rebxl.pdf

[8] UNESCO. (1979). Declaration on Race and Racial Prejudice; twentieth session-article two-1978: Paris page 2. 
(Adopted by the General Conference of UNESCO at its twentieth session. Paris). Retrieved from https://docplayer.net/9140719-Declaration-on-race-andracial-prejudice.html

[9] Young, R. J. (2003). Postcolonialism: A very short introduction. Oxford University Press.

Retrieved from https://globalasymmetries.files.wordpress.com/2014/09/c2_ young-2003_postcolonialism-a-very-short-

introduction_fragments.pdf 